\title{
Digital activism through online petition: A challenge for digital public sphere in Indonesia
}

\author{
Kun Sila Ananda* \& Megasari Noer Fatanti \\ Universitas Negeri Malang, Malang, Indonesia
}

\begin{abstract}
The increased use of internet not only for business, education, or entertainment but also for expressing opinion and digital activism signified that public sphere could also take place virtually through the internet. This paper aims to explore the digital activism done by Indonesian netizens through online petitions, and how it challenged the possibility of online petition as a form of the digital public sphere in Indonesia. The methods used is literature study on various works of literature and recent petitions in Change.org. This research shows that online petition provides a space for interaction between the marginalized groups, netizens, and the government. Online petitions also facilitate a new form of protest with more dynamic characteristics, including fast and effective communication. Online petition also gives the same right for every citizen to express their concern. However, online petition did not provide much space to promote a critical and deliberative public debate for public.
\end{abstract}

Keywords: Internet, Digital, Public Sphere

\section{INTRODUCTION}

Late in 2015, social media was buzzing about GoJek's ban on operations, online motorcycle taxi services, and similar businesses. The topic of GoJek heated up on social media until President Joko Widodo had to intervene. In just one night, Jokowi was able to undo the regulations made by The Minister of Transportation Ignasius Jonan. This kind of social movement is not only happening in Indonesia. Social media such as Facebook, Twitter and YouTube were considered to hold the key to student protests in Britain at the end of 2010. Social media also played a crucial role in the Tunisian and Egyptian revolutions, as well as mass protests on Wall Street about global capitalism in the United States (SEN 2012). This phenomenon revives the debate about the concept of the digital public sphere.

However, until now, the search for the public sphere that is considered ideal in the digital realm is never over. Experts have always compared the concepts of the public sphere in the digital world to the concept of the public sphere that Jurgen Habermas first used. Meanwhile, with the development of information and communication technology, the community continues to evolve along with the development of ways to communicate. Even today, it can be said that Indonesian society has not only entered the digital age but has entered the era of social media which is characterized by the use of social media as one of the primary media to communicate, as well as the use of social media that has become a significant and essential part of everyone's life.

This paper, therefore, tried to explore the digital activism done by Indonesian netizens through online petitions, and how it challenged the possibility of online petitions as a form of digital public sphere in Indonesia.

*Corresponding author: kun.ananda.fis@um.ac.id 


\section{LITERATURE REVIEW}

\subsection{Online petition}

Lindner and Riehm (2011:3) define petitions as requests to public authorities, usually governmental or parliamentary institutions. Petitions aim, among other things, to change public policy or encourage specific actions by public institutions (Lindner \& Riehm 2011:3). With the development of communication and information, technology presents online petitions as a new form of traditional petition. The presence of these online petitions has the same functionality as traditional petitions, but also offers a wider range of access in shorter time periods. Online petitions improve the democratic process, connect citizens with the government, and facilitate citizen involvement (Panagiotopoulos \& Al-Debei 2010:3).

\subsection{Digital activism}

Earl and Kimport (2008: 452-453) describe some form of online activism online. The four forms of online activism are petitions, boycotts, e-mailed letters of objection and campaigns. Of these forms of online activism, all are forms of interaction between netizens and those who have power. From various forms of events that occur, individuals as self-respond to such events into the form of confirming the truth of the information, translating information into individual expressions and then making decisions on whether this information will be acted upon as action.

\subsection{Habermas'public sphere}

Jurgen Habermas describes the concept of public space as an independent and separate space from the state and market where every citizen has equal access to public opinion. Habermas believes that the concept of the public sphere is an ideal concept for the prospects of democracy today (Subijanto 2014). With the development of information and communication technology, as well as the emergence of the internet, of course, the structure of public space is no longer the same as the first used by Habermas. Here are some comparisons between public spaces in Habermas time and public spaces that existed in the virtual world (cyberspace).

One of the most striking difference between the concept of Habermas public room and public space in virtual space is that in virtual public spaces, participants are not only dominated by one particular person. Participants in virtual public spaces are also not limited by spaces, such as country and place borders. In the virtual realm, anyone can participate in discussing issues that they find interesting. Not only has the shape of public space changed, the concept of citizens as 'residents' of public spaces has also changed. Anyone can participate in a virtual public space, be it a citizen of a country abroad, or a citizen of the world who wants to give an opinion on an issue in a country.

\section{METHODS}

The methods used is literature study on various works of literature. The secondary data also collected from Change.org as an online platform by exploring recent petitions in Change.org including petition such as Reject RKUHP Bill, Amnesty for Nuril, Reject Music Bills, also petitions with hashtag \#ReformasiDikorupsi. This research also analyzes the statement by Change.org representatives in online media news as secondary data. 


\section{RESULT AND ANALYSIS}

\subsection{Online petition as digital activism}

What netizens do through their change.org is one form of online activism. Change.org petitions cannot be separated merely as a stand-alone form of a petition. The electronic petition (e-protest) here describes a combination of other forms of activism, such as letters of objection, campaigning by e-mail and of course some cases are open boycotts. One example is a petition demanding the concern of the Indonesian government and the Malaysian government in Wilfrida Soik's release in the alleged corruption of her employer in Malaysia. The petition, written by Anis Hidayah, an activist for Migrant Care is an attempt to represent how information obtained through the Migrant Care network in the area managed to find the facts about age forgery, moratorium violations and alleged mental disorders experienced by Wilfria Soik. All media works, including social media such as Facebook, Youtube, Twitter and Path. All of this is a form of cooperation between the organs of society in managing information, changing it in the form of expressions and actions that correspond to their respective capacities. In change.org, the whole strategy is combined into a real movement.

We see that change.org is not solely a form of spatial space or a medium of regular interaction. Some sociologists who paid attention to the conception of space such as Simmel, Foucault and Lefebvre reintroduced space as a form of spatial consciousness. Here Lefebvre (1991:26) believes that space is socially produced and becomes the centre of attention in the theory of social sciences. With the idea of spatial awareness, we can translate the space as a tool of thought and at the same time as a tool of action (action) be it in production, surveillance (control), dominance and power. Therefore, we see the change.org as a space of spatial awareness as conveyed by Lebfevre. In change.org, individuals not only product information, but also become an information management room that acts as a tool of thinking (in the form of discussion and discursus) as well as a new tool of struggle called e-protest which refer to a revolutionary stage in the issues of social movements in Indonesia.

\subsection{Public sphere in Indonesia}

Based on Subijanto (2014), in Indonesia post-1998, two institutions are often considered manifestations of the public sphere, namely media and non-governmental organizations (NGOs). But as an institution supported by donor institutions from developed countries and even transnational corporations, there are political and economic motivations that can influence the performance of NGOs following the interests of donor institutions. Also, NGOs become apolitical public spaces and are not used to criticize the government following public views and interests.

Meanwhile, the emergence of the television industry then also gave rise to discourse about the public sphere in the form of mass media. In 1989, after Habermas's work was translated into English, the public sphere defined as an area accessible to everyone without restrictions. Public space is no longer physical but becomes a virtual community with the same function, which is to play a critical role in politics. However, considering that television and other media are still controlled by corporations and are still profit-oriented organizations, it is hard for television to be a neutral public sphere. Besides, the mass media also does not meet the egalitarian nature of Habermas's public spaces.

Furthermore, as digital media technology evolves, the internet and social media again give hope as a potential platform to become a public sphere. DiMaggio et al. (2001:319) revealed that the advent of the internet gave the possibility of an up-to-date public sphere. The enthusiasm found early evidence that the internet could form a more deliberative community and a more engaged public. The advent of the internet does provide people with easy access to information, including political information, as well as providing space to express their opinions freely. 


\subsection{Online petition as a public sphere}

Online petitions are a form of political participation that connects people with the government. Petitions always related to mass movements or social movements. It is because the essence of the petition is the gathering of public opinion as well as the fundraising of support that allows for change, whether in terms of policy or other. Social movements can also be referred to as movements born from and on the initiative of society to demand changes in both the realm of institutions and government policy.

Founded in 2007, change.org was initially used as a social network for social activities, then turned into a blog, and changed again to an online petition website in 2011. In Indonesia itself, change.org has opened a representative office in Indonesia on June 4th, 2012. Up till now, its membership increased rapidly to 71,000 people and continued to increase to this day. Every petition uploaded and signed will go to government e-mails or state officials, among others are the emails of the President, the police chief, and some members of Commission III of the House of Representatives. Campaigns and fundraisers through this petition are usually also spread through social media for maximum results.

When compared to the concept of public space from Habermas, online petition platforms such as change.org have some advantages and disadvantages. As a non-profit platform, change.org does not sponsor a particular petition, or attempt to popularize petitions. By using the internet and social media, online petitions can also reach more audiences, and efforts to gather support are relatively easy. Internet users only need to click "sign the petition," and their support is immediately counted. Also, another advantage that online petitions have that in line with Habermas' public space structure is the equality in it. Anyone can create a petition and sign a petition. Change.org also fulfill the anonymity element in Habermas's public spaces.

However, online petitions also have drawbacks, including only supporting one-way communication. Change.org does not allow for deliberative and critical discussions between users. Another drawback of change.org is the lack of openness from change.org management to users, such as the placement (display) of petitions. Some petitions are placed in front of a large, easy-to-see display, while others are not. The placement criteria (display) of this petition are not yet known. Social media can complement the shortcomings of the change.org online petitions and the alternative public space in this virtual world. Social networks such as Facebook and Twitter can not only be used to popularize a petition. Therefore, online petitions and social media can be two types of complementary platforms to become alternative public spaces in Indonesia. Combined, the use of both could meet Habermas public space criteria such as egalitarian, critical and deliberative discussions, anonymity or equality between users, censorship-free, and openness

\section{SUMMARY}

Netizen participation in giving their opinion about social and political issues increased over the years. The online petition provides a space for interaction between the marginalized groups, netizens, and the government and facilitates a new form of protest with more dynamic characteristics. These aspects of online petition fulfil Habermas's concept about the public sphere, which mobilizes public concern and participation openly, equally and anonymously. However, in other aspects, the online petition did not provide much space to promote a critical and deliberative public debate for the public, and the lack of openness of change.org as a platform creates a bias on popular or promoted petitions.

\section{REFERENCES}

DiMaggio, P. et al. (2001) 'Social implications of the internet', Annual Review of Sociology. doi: 10.1146/annurev.soc.27.1.307. 
Lindner, R. and Riehm, U. (2011) 'Broadening Participation Through E-Petitions? An Empirical Study of Petitions to the German Parliament', Policy \& Internet. doi: 10.2202/1944-2866.1083.

Panagiotopoulos, P. P. (2010) 'Engaging with Citizens Online?: Understanding the Role of ePetitioning in Local Government Democracy', in Internet Politics Policy 2010 An Impact Assessment.

Sen, A. F. (2012) 'The social media as a public sphere: The rise of social opposition', in International Conference on Communication, Media, Technology and Design.

Subiakto, Henry and Ida, R. (2014) Political, Media, and Democratic Communication. 2nd edn. Jakarta: Kencana Prenadamedia Group.

Subijanto, R. (2014) Public Spaces Then and Now. Available at: http://indoprogress.com/2014/04/ruangpublik-dulu-dan-sekarang/ (Accessed: 1 January 2016). 